\title{
Perception of Small and Medium Entrepreneurship in the Czech Republic
}

- Smékalová Lenka, Hájek Oldrich, Belás Jaroslav, Macháček Jirú

\begin{abstract}
This paper deals with small and medium enterprises in relation to the attitudes perceived by business owners in their immediate neighbourhood, society, in relation to banks and the government. The key question is the difference between entrepreneurs who started their businesses voluntarily and those who entered the business out of necessity. The majority of governmental policies, including Czech policies, focus more on the questions of financial support, however the support of entrepreneurs can be broader and may include the efforts to influence perception of an individual and the society so that they have a more positive attitude towards entrepreneurial activities. The attitudes in the Czech Republic are so far rather negative and such a change may be positively reflected in the level of the entrepreneurial activity which strongly affects economic development.
\end{abstract}

Keywords: small and medium enterprises, survey, business owners, perception of entrepreneurial activities JEL Classification: G28, G32, L26

\section{INTRODUCTION}

Who is an entrepreneur? What is an enterprise? This question has presently multiple answers depending on the scope of particular research or use. And while there are multiple definitions of both (see e.g. Hölzl, 2010, Iversen et al., 2008, Grebel et al., 2003) there is quite a unanimous belief that the entrepreneurs and entrepreneurship are important for economic development of states and regions, their competitiveness and sound development of macroeconomic indicators (e.g. Baumol, 2002, Audretsch, 2004, Ivanová, 2011, Vojtovich, 2013).

Bruyat and Julien (2001) summarize previous historical approaches to the definition of entrepreneurs into three groups:

- a Cantillon definition of entrepreneur claim entrepreneur is someone who takes a risk and may benefit,

- a Turgot and Saye definition perceives an entrepreneur as anyone who has production factors and organizes the production of new values

- a Schumpeterian definition of entrepreneur see an entrepreneur solely in creators of any innovation.

The authors themselves then propose to look at entrepreneurs as individuals forming new value. Finally, in light of the definition of the European Commission (2003) an entrepreneur is an entity engaged in any economic activity, regardless of its legal form. 
The perceived importance of the entrepreneurs for economic development results in multiple studies directed at this research area. Van Stel at al. (2005) provide comparison of data from 36 national states and conclude that there is indeed a relationship between entrepreneurial activity and economic growth. Wennekers et al. (2005) confirm a hypothesis of dependence between the economic performance measured by the size of the income per capita in purchasing power parity and the number of newly established business entities. Wennekers et al. (2010) then examined the relationship between the overall business activities of enterprises in the early stages of development and economic performance resulting in certain recommendations for political decision makers.

The research and the support schemes for entrepreneurship activity are mostly aimed at the small and medium enterprises due to their perception as exceptionally flexible and of great importance in national economy (e.g. Bruce, 2009). However, there are certain negatives strongly connected with the position of an entrepreneur as a micro, small or medium enterprise. The most glaring one is especially in their position in relation to obtaining financial resources and then engaging them in areas of innovations, research and development (Tödtling \& Kaufmann, 2001, Müller \& Zimmermann, 2009) which renders the enterprises especially vulnerable to recent negative economic development (Mulačová, 2012). Particularly in the Czech Republic the question also remains of the small and medium enterprises and their relationship in connection with public procurement (Jurčík, 2013, Jurčík, 2012). Lastly but not at least smaller forms of entrepreneurship are rather more influenced by the overall perception of entrepreneurial activity in particular country or region (Srpová, Řehoř et al., 2010).

However, the influence of entrepreneurial activity on economic development is not solely a question of size of entrepreneurs or of the grant schemes. It is strongly dependent on individuals and particularly on their decision about establishing a new entrepreneurial unit. Acs and Varga (2005) distinguish between the case of establishing a business out of necessity when an individual starts a business only because it is the best possible option, and a business establishment based on the options that the individual understands and wishes to explore. The latter form of business establishment generates according to their larger number jobs and more prosperous entrepreneurs thus it contributes to a greater extent to improvement of the economic performance.

This paper aims to analyse entrepreneurial perceptions of Czech entrepreneurs in order to establish greater awareness of their needs that should be met by a national entrepreneurial support schemes in a less traditional sense than the direct financial support of the entrepreneurs.

\section{METHODOLOGY}

The entrepreneurial perception was researched by means of questionnaire distributed among the group of the owners of micro, small and medium enterprises in the Zlín Region. The distribution was based on personal meetings of the research team with the entrepreneurs who were selected based on the size of the enterprise with exclusion of the large companies. The pre-selection was focused especially on companies that have previously cooperated with the Tomas Bata University especially within the frame of the project no. CZ.1.07/2.2.00/15.0366 "Teaching entrepreneurship at Tomas Bata University in Zlín”. Approximately $30 \%$ of business owners agreed to personal meeting where they would fill the questionnaire. 
The survey itself was carried out through October and November 2013 and the pre-selection of entrepreneurs known for cooperation with the university ensured high return rate of almost $95 \%$. The questions were constructed with regards to previously mentioned theoretic concept of the differences that stem from the primary motivation for starting one's own business. The now business owners initially either entered the business voluntarily or out of necessity. Since the literature sees greater potential in the first mentioned group following hypotheses regarding entrepreneurs and their surroundings were made:

H1: Entrepreneurs note difference in perceived attitudes of immediate surrounding and the overall society, the difference is statistically significant.

H2: Business owners who established their business voluntarily perceived attitudes of banks and of the government more positively than entrepreneurs who established business out of necessity.

H3: Owners of the voluntarily established businesses have more positive expectations with regards to successful existence of the business.

In order to prove or disprove the abovementioned hypotheses a series of null hypotheses was made:

$\mathrm{H}_{01}$ : The attitudes of immediate surroundings and overall society as perceived by the entrepreneurs do not exhibit statistically significant difference.

$\mathrm{H}_{02}$ : There is no statistically significant difference in attitudes concerning banks and government support between the business owners who established their business voluntarily and those who started them out of necessity.

$\mathrm{H}_{03}$ : There is no statistically significant difference between voluntary business owners and others in relation to expectations of the viability of the businesses.

\section{RESULTS}

The questionnaire was answered by 180 business owners out of whom $58 \%$ were the owners of microenterprises, $31 \%$ of small and $11 \%$ of medium enterprises.

In reflection of the importance of the primary motivation for establishing the business the survey distinguished between two categories - staring business out of necessity (lack of employment and connected monetary issues) and staring business voluntarily (in order to achieve selffulfillment, from desire to try running a business, seeing business as a mission). The respondents of the survey mostly professed to have started their business out of necessity (65\%). The variance was very small among the size categories of business and the hypothesis of their equality in motives for establishing business was not disproved statistically when using the chi-square test (see tab. 1). Therefore we can conclude that regardless of business size the majority of the owners established their business out of necessity rather than voluntarily which according to previously mentioned theory bodes rather ill for long term success of the business. 
Tab. 1 - Statistical test of dependence between business size and voluntarism in business establishment. Source: Authors' calculations.

\begin{tabular}{|l|l|}
\hline Chi-square & 0,213 \\
\hline P-value & 0,899 \\
\hline
\end{tabular}

The questionnaire further addressed the entrepreneurial perception of attitudes their close environment and the society as a whole have towards their activities. The immediate surroundings of the entrepreneurs record more positive attitude often referred to as a support of entrepreneurial activity which is somewhat stronger in entrepreneurs who started the business voluntarily than in those establishing themselves as entrepreneurs from sheer necessity. However, the entrepreneurs themselves feel that in the society as a whole prevail more negative views of entrepreneurship. Curiously enough this perception is stronger in voluntary entrepreneurs (see pic. 1).

The perception of the banks in relation to loans provided to SMEs is rather negative $35 \%$ of the respondents feels the banks have more negative attitude, $39 \%$ feels neutral attitude and only 4,5 $\%$ perceive encouragement and positive approach when applying for a loan. These attitudes are perceived similarly notwithstanding the motivation for business establishment.

The attitudes towards public support of the entrepreneurs are distinctly negative. More than 70 $\%$ of entrepreneurs do not regard government financial support of entrepreneurial activities as rightly aimed, 21,5\% do not have an opinion and only 7,7 \% regard government financial support positively. It is necessary to note that almost two thirds of them deny ever making use of any governmental support.

The outlook of the entrepreneurs towards the future is however, rather positive. Sole entrepreneur claims certainty of the business closing down in following 5 years, others deem their business will either most certainly survive (49,5\%), or survive with more $(4,5 \%)$ or less $(45,5 \%)$ significant difficulties.

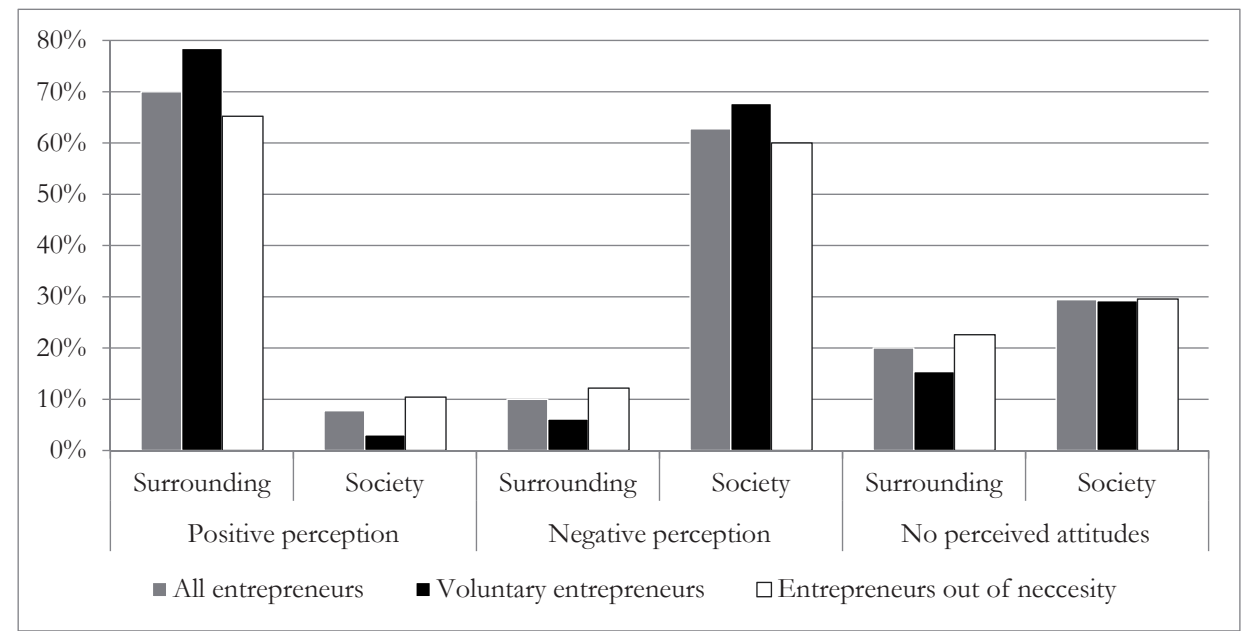

Fig. 1- Attitudes the entrepreneurs perceived in their surroundings and in the society. Source: Authors. 
In order to prove or disprove the null hypotheses series of statistical chi-quadrate test were made with results depicted in table 2 . Based on the value of chi-square and corresponding p-value the authors cannot disprove the aforementioned null hypotheses. Concluding these is no statistically significant difference between perceiving the attitudes of those in immediate vicinity of the entrepreneurs and the attitudes of the society. The question of statistical significance, however, does not altogether exclude matter of factual dependence as suggested by simple analysis which shows more positive attitudes of the neighbouring elements in comparison to the whole society.

There is no statistical difference in matter of entrepreneurial perception of the attitudes of banks and the government. Neither was the dependence of the abovementioned on the voluntarism in the business establishment evident factually in survey analysis.

While statistically significant difference was not observer in the future outlook of the entrepreneurs factually the outlook of the voluntary entrepreneurs in more positive as none of them have expressed belief in the cessation of their own business or significant difficulties while non-voluntary entrepreneurs did.

Tab. 2 - Statistical test of appointed hypotheses. Source: Authors' calculations.

\begin{tabular}{|l|c|c|}
\hline Hypothesis & Chi-square & P-value \\
\hline $\mathrm{H}_{01}$ & 5,73 & 0,22 \\
\hline $\mathrm{H}_{02}$ for banks & 0,14 & 0,98 \\
\hline $\mathrm{H}_{02}$ for government & 2,06 & 0,37 \\
\hline $\mathrm{H}_{03}$ & 2,38 & 0,31 \\
\hline
\end{tabular}

A negative image of entrepreneurs is by no means limited to the Czech entrepreneurs. Similar attitudes are reported in other post-communist countries such as Russia, Poland, East Germany (Timofeyev, 2010, Stephan et al. 2007, Okwiet, 2013, Komadinić \& Ilić, 2013) but also in western countries with studies made in France, Germany or overseas in Chile (Achtenhagen \& Welter, 2006, Fayolle, 2000 or Isenberg, 2010). The reasons for the negative image of entrepreneurs vary in time and regions but often stem from the fact that people regard them as rather inconsiderate individual pursuing solely their own benefit, monetary or otherwise (Bergmann, 2002). Particularly in post-communist countries the matters of privatization of the formerly state business creates basis for critique of entrepreneurs, however, an American study by Allen (2000) confirms that even in western countries some people express negative opinions toward entrepreneurs on basis of their own belief they cheated to achieve their present success.

The present initiatives that are focused on education for entrepreneurship are widespread and have history that in some countries dates into the immediate post WWII era (Katz, 2003). Currently the education for entrepreneurship, particularly for economically active people, is seen as an indispensable measure in stabilizing labour markets affected by the economic crisis. In the Czech Republic there is currently no compulsory subjects within the primary education that would address entrepreneurship directly, this topic is addressed more directly during the 
secondary education phase with the emphasis on possible career options for the students (Eurydice, 2012). The most practical approach is taken by introducing the practice firms in secondary education and the Junior Achievement Company Programme, although European Commission (2009) points out the problem of few school participating. The entrepreneurship education at the universities was rather thoroughly investigated by Varblane and Mets (2010). In the case of the Czech Republic the authors identified that about one third of studies institutions offered courses targeting the future entrepreneurship with some of the best practice examples included.

While the government's options on influencing the ultimate image of entrepreneurs are somewhat limited mostly due to intensive media involvement the key role may very well rest in gradual change in attitudes beginning early in an individual's life. As was previously mentioned the negative image of entrepreneurship is often caused by historical and cultural reasons which are slow to change and best influenced in young generation. Therefore the cultivation of a positive attitude towards entrepreneurs and their activities should start in educational system with introduction of entrepreneurship and support of entrepreneurial attitude in young people who will carry this attitude thorough their lives. That is not to say the governmental policy should resign on changing the opinion of older citizens, however, the propagation of entrepreneurship will most likely yield not the same results as in younger people. At the same time a positive attitude towards entrepreneurship may influence the young people to engage in their own entrepreneurial activities to the benefit of the entire national economy.

\section{CONCLUSION}

While the government support of the entrepreneurs most often focuses on the questions of finance the results of this particular research show that at least in the Czech Republic the entrepreneurs have to deal with additional strains presented by both the immediate surroundings and the attitudes of the entire society and the overall efforts of the government are perceived rather negatively. It is therefore a new question for the government policy whether it should add a new level of entrepreneurial support that would more clearly address the society and the sum of rather negative feelings towards the entrepreneurs which would possibly encourage more voluntarily based establishments of the businesses with owner who are strongly supported by their immediate environment have positive or neutral relationship with financial institutions and are more optimistic with regards to their own future and businessmen. The key to a long term positive attitude towards entrepreneurs lies most likely in the future and presently is at hands of the educators who have the opportunity to foster positive attitude of the youth who will carry it into their active working life and may become entrepreneurs themselves as evidenced by initiatives undertaken both in the European Union and the United States which promote introduction of entrepreneurship related activities to the educational systems (see e.g. O'Connor, 2013) with the understanding that education alone is not entirely sufficient and should be complemented by other personal and systemic characteristics (Dutta \& Li \& Merenda, 2011), not all of them within the purview of a government. 


\section{Acknowledgement}

This paper was supported by Project No. FaME/2013/MSPRISK: Aktuálne trendy v oblasti podnikatelských rizík malých a stredných firiem vo vybraných krajoch ČR a SR.

The authors are thankful to the Operational Programme Education for Competitiveness co-funded by the European Social Fund (ESF) and national budget of the Czech Republic for the grant No. CZ.1.07/2.3.00/20.0147 - "Human Resources Development in the field of Measurement and Management of Companies, Clusters and Regions Performance", which provided financial support for this research.

\section{References}

1. Acs, Z. J., \& Varga, A. (2005). Entrepreneurship, Agglomeration and Technological Change. Small Business Economics. 24(3), 232-334. http://dx.doi.org/10.1007/s11187-012-9418-z

2. Achtenhagen, L., \& Welter, F. (2006). Re-creating an Entrepreneurial Spirit in Germany: A Review of the Public and Newspaper Discourse, paper presented at the Rencontre de St-Gall, Switzerland, September 2006.

3. ALLEN, W. D. (2000). Social networks and self-employment. The Journal of socio-economics. 29(5), 487-501. http://dx.doi.org/10.1016/s1053-5357(00)00086-x

4. Audretsch, D. B. (2004). Sustaining Innovation and Growth: Public Policy Support for Entrepreneurship. Industry and Innovation. 11(3), 167-191. http://dx.doi.org/10.1080/1366271 042000265366

5. Baumol, W. J. (2002). Free-Market Innovation Machine: Analysing the Growth Miracle of Capitalism. Princeton: Princeton University Press.

6. Bergmann, H. (2002). Entrepreneurial attitudes and start-up attempts in ten German regions. An empirical analysis on the basis of the theory of planned behaviour. Working Paper, University of Cologne.

7. Bruce, D., Deskins, J. A., Hill, B. C., \& Rork, J. C. (2009). (Small) Business Activity and State Economic Growth: Does Size Matter? Regional Studies. 43(2), 229-245. http://dx.doi. org/10.1080/00343400701808915

8. Bruyat, C., \& Julien, P. A. (2001). Defining the Field of Research in Entre-preneurship. Journal of Business Venturing. 16(2), 165-180. http://dx.doi.org/10.1016/s0883-9026(99)00043-9

9. Dutta, D. K., Li, J., \& Merenda, M. (2011). Fostering entrepreneurship: impact of specialization and diversity in education. International Entrepreneurship and Management Journal, 7(2), 163-179. http://dx.doi.org/10.1007/s11365-010-0151-2

10. European Commission (2003). Commission Recommendation of 6 May 2003 Concerning the Definition of Micro, Small and Medium-sized Enterprises, (2003/361/EC). In EUR-Lex.europa.eu [online]. Retrieved October 15, 2013, from http://eur-lex.europa.eu/ LexUriServ/LexUriServ.do?uri=OJ:L:2003:124:0036:0041:EN:PDF

11. European Commission (2009). Best Procedure Project: 'Entrepreneurship In Vocational Education And Training', Final Report Of The Expert Group [online]. Retrieved December 2, 2014, from http://ec.europa.eu/enterprise/policies/sme/files/smes/vocational/entr_voca_en.pdf

12. Eurydice (2012). Entrepreneurship Education at School in Europe. Brussels: Education, Audiovisual and Culture Executive Agency. 
13. Fayolle, A. (2000). Exploratory study to assess the effects of entrepreneurship programs on French student entrepreneurial behaviors. Journal of Enterprising Culture, 8(2), 169-184. http://dx.doi.org/10.1142/s0218495800000103

14. Grebel, T., Pyka, A., \& Hanusch, H. (2003). An Evolutionary Approach to the Theory of Entrepreneurship. Industry and Innovation. 10(4), 493-514. http://dx.doi.org/10.1080/136627 1032000163702

15. Hölzl, W. (2010). The Economics of Entrepreneurship Policy: Introduction to Special Issue. Journal of Industry, Competition and Trade. 10(3/4), 187-197. http://dx.doi.org/10.1007/ s10842-010-0088-8

16. Isenberg, D. J. (2010). How to start an entrepreneurial revolution. Harvard Business Review, $88(6), 40-50$.

17. Ivanová, E. (2011). The Quality of Human Resources as a Factor of Competitiveness. In Proceedings from the 9th International Conference Economic Policy in the European Union Member Countries, 2011. 167-181.

18. Iversen, J., Jorgensen, R., \& Malchow-Moller, R. (2008). Defining and Measuring Entrepreneurship. Foundations and Trend in Entrepreneurship. 4(1), 1-63. http://dx.doi. org $/ 10.1561 / 0300000020$

19. Jurčík, R. (2012). Aktuální trendy legislativy veřejného investování v České republice a Evropské unii -- symbióza či disharmonie? Veréjné zakáaky a PPP projekty. 4(3), 9-13.

20. Jurč́k, R. (2013). Small and Medium Size Enterprises (SME) and public procurement. In LORCA, P. a POPESCU, C. Recent Researches in Applied Economics and Management - Volume I. Wseas Press, 335-340.

21. Katz, J. A. (2003). The chronology and intellectual trajectory of American entrepreneurship education. Journal of Business Venturing, 18(2), 283-300. http://dx.doi.org/10.1016/s08839026(02)00098-8

22. Komadinić, V., \& Ilić, D. (2013). Risk assessment in small and medium-sized enterprises, specifics and differences in approach. Journal of Applied Engineering Science, 11(3), 123-126.

23. Mulačová, V. (2012). The Financial and Economic Crisis and SMEs. Littera Scripta. 5(2), 95-103.

24. Müller, E., \& Zimmermann, V. (2009). The Importance of Equity Finance for R\&D Activity. Small Business Economics. 33(3), 303-318. http://dx.doi.org/10.1007/s11187-0089098-x

25. O’Connor, A. (2013). A conceptual framework for entrepreneurship education policy: Meeting government and economic purposes. Journal of Business Venturing, 28(4), 546-563. http://dx.doi.org/10.1016/j.jbusvent.2012.07.003

26. Okwiet, B. (2013). Entrepreneurship in small and medium enterprises sector: development barriers and opportunities. Polish Journal of Management Studies, 7(1), 37-47.

27. Srpová, J., Řehoř, V. et al. (2010). Zákelady podnikání. Vydání první. Praha: Grada.

28. Stephan, U., Lukes, M., Dej, D., \& Richter, P.G. (2007). Attitudes towards and Perceptions of Entrepreneurs in Central Eastern Europe (Poland, the Czech Republic, East-Germany). 
In Perspectives and Progress in Contemporary Cross-Cultural Psychology (G. Zheng, K. Leung, \& J. Adair (Eds). Beijing: China Light Industry Press.

29. Timofeyev, Y. (2010). Socio-Cultural Practices and Restrictions of Entrepreneurship in Transition Russia. In: The Sixth Annual Meeting of Chinese Hayek Society. August 10, 2010, Shue Yan University. http://dx.doi.org/10.2139/ssrn.1755334

30. Tödtling, F., \& Kaufmann, A. (2001). The Role of the Region for Innovation Activities of SMEs. European Urban and Regional Studies. 8(3), 203-215. http://dx.doi.org/10.1177/0969776 40100800303

31. Van Stel, A., Carreee, M., \& Thurik, R. (2005). The Effect of Entrepreneurial Activity on National Economic Growth. Small Business Economics. 24(3), 311-321. http://dx.doi. org/10.1007/s11187-005-1996-6

32. Varblane, U., \& Mets, T. (2010). Entrepreneurship education in the higher education institutions (HEIs) of post-communist European countries. Journal of Enterprising Communities, 4(3), 204-219. http://dx.doi.org/10.1108/17506201011068219

33. Vojtovich, S. (2013). The Impact of Emigration on Unemployment in Slovakia. Engineering Economics. 24(3), 207-216. http://dx.doi.org/10.5755/j01.ee.24.3.3173

34. Wennekers, S., Van Stel, A., Thurik, R., \& Reynolds, P. (2005). Nascent Entrepreneurship and the Level of Economic Development. Small Business Economics. 24(3), 293-309. http:// dx.doi.org/10.1007/s11187-005-1994-8

35. Wennekers, S., Van Stel, A., Carree, M., \& Thurik, R. (2010). The Relation between Entrepreneurship and Economic Development: Is It U-Shaped? Foundations and Trend in Entrepreneurship. 6(3), 167-237.

\section{Contact information}

Ing. Lenka Smékalová

Tomas Bata University in Zlin, Faculty of Management and Economics

Mostni 5139, 76001 Zlin, Czech Republic

Email:smekalova@fame.utb.cz.

assoc. prof. RNDr. Oldrich Hájek, Ph.D.

Tomas Bata University in Zlin, Faculty of Management and Economics

Mostni 5139, 76001 Zlin, Czech Republic

Email:hajek@fame.utb.cz.

assoc. prof. Ing. Jaroslav Belás, Ph.D.

Tomas Bata University in Zlin, Faculty of Management and Economics

Mostni 5139, 76001 Zlin, Czech Republic

Email:belas@fame.utb.cz.

Ing. Jirí Macháček

Tomas Bata University in Zlin, Faculty of Management and Economics

Mostni 5139, 76001 Zlin, Czech Republic

Email:machacek@fame.utb.cz. 